\title{
Women successor selection
}

\author{
Selección de mujeres sucesoras \\ Argentina Soto Maciel $^{1}$, Juan Manuel San Martín Reyna*2, \\ María Isabel de la Garza Ramos ${ }^{3}$, José Luis Esparza Aguilar ${ }^{4}$ \\ ${ }^{1}$ Universidad Anáhuac México, México \\ ${ }^{2}$ Universidad de las Américas Puebla, México \\ ${ }^{3}$ Universidad Autónoma de Tamaulipas, México \\ ${ }^{4}$ Universidad de Quintana Roo, México
}

Received February 25, 2019; accepted September 25, 2020

Available online October 2, 2020

\begin{abstract}
The research of the role of women within organizations, studied since different disciplines, has been increasing to try to find out the causes of the lag in their participation; this concern increases when she is a member of a family-owned business. The relevance of the family business in the economy of a country, have increased the interest in knowing it in the last 40 years. Given the prevailing difference regarding access and development within the family business, the question arises about the expectations of women in the succession process. The aim of this research is to identify the factors that influence the decision of the selection of a woman to succeed in the direction of the family business in the next generation. To achieve this, 652 owners of family businesses in four states of the Mexican Republic were surveyed, using a Logit model for their analysis. The results show an important gender influence, since the presence of a female family member in the property and the management will positively influence the selection of another woman. Likewise, the age of the company, its size, and the sector in which it operates are influencing factors.
\end{abstract}

JEL Code: M10, M20, M21

Keywords: Family business; Women; CEO; Successor selection

\footnotetext{
${ }^{*}$ Corresponding author.

E-mail address: juanm.sanmartin@udlap.mx (J.M. San Martín Reyna).

Peer Review under the responsibility of Universidad Nacional Autónoma de México.
} 


\section{A. Soto Maciel, et al. / Contaduría y Administración 66(3), 2021, 1-14 \\ http://dx.doi.org/10.22201/fca.24488410e.2021.2482}

\section{Resumen}

La investigación del papel de la mujer dentro de las organizaciones, estudiado por diversas disciplinas, ha ido incrementándose para intentar conocer las causas del rezago de su participación; esta inquietud aumenta cuando ella es un miembro de una empresa de propiedad familiar. La empresa familiar es considerada por su relevancia en la economía de un país, aumentando el interés por conocerla en los últimos 40 años. Ante la diferencia que prevalece en lo referente al acceso y desarrollo dentro de la empresa familiar, surge el cuestionamiento sobre las expectativas de la mujer en el proceso sucesorio. El objetivo de esta investigación es identificar los factores que influyen en la decisión de la selección de una mujer para suceder en el mando de la firma familiar en la siguiente generación. Para lograrlo, se encuestó a 652 directores propietarios de empresas familiares en cuatro estados de la República, utilizando para su análisis un modelo Logit. Los resultados muestran una importante influencia de género, ya que la presencia de un miembro femenino de la familia en la propiedad y la dirección influirá positivamente en la selección de otra mujer. Asimismo, son factores de influencia la antigüedad de la empresa, su tamaño y el sector en el que radica.

Código JEL: M10, M20, M21

Palabras clave: Empresa familiar; Mujer; Director general; Selección del sucesor

\section{Introduction}

The participation of women within organizations is being studied from different perspectives: their presence in senior management (Moreno, Lafuente and Vaillant, 2018); entrepreneurship and innovation based on their personal and commercial peculiarities (Agarwal, 2019); the characteristics and problems of SMEs led by female managers (Camarena, Saavedra, and Ducloux, 2016); the relationships between the participation of women in property and the financing decisions of SMEs (Briozzo, Albanese and Santolíquido, 2017) and others.

On one side, the importance of family businesses in national economies has been widely recognized in various countries. However, research on this type of organization is relatively recent, barely forty years old. Nevertheless, the results have allowed us to recognize that the management and commercial behavior of these businesses are significantly influenced by the overlap of business and family (Chrisman, Chua, Le Breton-Miller, Miller, and Steier, 2018).

In this sense, Latin America is not the exception, it is estimated that 9 out of 10 companies are family business (Belausteguigoitia, 2017). In Mexico, $99.8 \%$ of the 4'230,745 total business units (INEGI, 2015) are micro, small, and medium, of which, close to $90 \%$ can be considered family businesses (Ferrón, Simón, Durán \& San Martín, 2016; Soto, Garza, Esparza \& San Martín, 2015). 
On the other hand, in the family-owned businesses research, succession is one of the most studied topics (De Massis, Sieger, Chua and Visnara, 2016; Richards, Kammerlander, and Zellweger, 2019), as well as its success factors. or failure (Le Breton-Miller, Miller and Steier, 2004), the social exchanges that take place (Daspit, Holt, Chrisman, and Long, 2016), as well as the influences of the current council president, family relationships, and the participation rate of external directors in selection decisions (Luan, Chen, Huang, and Wang, 2016).

In the succession process, actions and events drive the transfer of knowledge, control (Cabrera-Suárez, 2005; De Massis, Chua and Chrisman, 2008) and business leadership (Sharma, Chrisman, Pablo and Chúa, 2001), bringing together, in this way, all the elements of a true challenge (Carr, Chrisman, Chua, \& Steier, 2016).

If we add the gender factor to the above, that challenge is further complicated. The disadvantage represented by the gender factor is well known in the family business literature, in a great majority of cases, when a female member of the family is among the candidates for succession (Beltrán, Haro, Bernal and Trueba, 2019).

Previous studies have found important factors that hinder and even impede the selection of a woman in the succession process such as: the birthright (Overbeke, Bilimoria and Pere1li, 2013); the preference for the male child (Glover, 2014); the conflict between home-mother-work roles (Cadieux, Lorrai and Hugron, 2002; Vera and Dean, 2005); and the ostensible perception of women about existing inequality (Gherardi and Perrotta, 2016). However, there is a lack of literature on this important topic to gain a better understanding of the selection factors related to the gender of the successor (Schröder, Schmitt \& Arnaud, 2011; Daspit, 2016; Richards, Kammerlander, \& Zellweger, 2019). Based on the above, the objective of this research is to identify the different factors that influence the decision that the selection to succeed in command of the family firm in the next generation is a woman.

The structure of the article, after this introduction, is as follows: a review of the literature on the subject and the methodology used is presented, pursued by the results, then the discussion and conclusions, to end with the bibliographic references.

\section{Literature Review}

To the date, there is no consensus to define family business and there is not be possible soon (Chrisman, Chua \& Sharma, 2005; Gallo, 2008). In spite of this, there are some similarities between scholars to consider a family business. One of them is property (Barnes \& Hershon, 1976; Gallo \& Sveen, 1991; Gallo, 1995); control (Davis, 1983; Stern, 1986); and generational transfer (Bork, 1986; Donnelley, 1988). For other authors property and direction are inseparables (Rosenblatt, De Mik, Anderson, \& Johnson, 1985). In this work, we consider a family business when the same family or related families own more than $50 \%$ of property, and at least one of the members is a part of the top management team. 
When analyzing the literature of succession, one of its crucial decision is the selection of a successor (Bertrand, Johnson, Samphantharak \& Schoar, 2008; Kammerlander, 2016) and, where gender is the main factor (Dumas, Dupis, Richer \& St-Cyr, 1995; Keating \& Little, 1997; Bayad \& Barbot, 2002). Women are not protagonists, the principal roles are left to incumbent and successor, typically identified as father and son (Cesaroni, Garcés, \& Sentuti, 2018). Evidence shows the preference of primogeniture of the male (Constantinidis, 2010; Glover, 2014; Ahrens, Landmann \& Woywode, 2015), where daughters and minor children are in lowest positions (Dumas, 1989, 1992; Barnes, 1988). But assigning a daughter a higher position than the child within the company lacks coherence with the family hierarchy (Barnes, 1988).

Women lacks acceptability, credibility and legitimacy of their parents to be considered like a potential successor (Bayad \& Barbot, 2002). Stavrou (1999) and Dumas (1998) also found that daughters, even being first-born, are not often considered for leadership roles in the family business; some owners prefer to sell the business instead of putting the daughter in charge. They have an implicit adherence to the practice of the offspring (Vera \& Dean, 2005). While the first-born male child is the successor or perceive their participation more as an employment, as a career opportunity (Vera \& Dean, 2005).

The contribution of women in family businesses is often limited to the fulfillment of inferior tasks (Dumas, 1992; Jiménez, 2009), and is not necessarily recognized by a position or salary. On the contrary, their efforts could be considered as minimal extensions of their roles and responsibilities in the home where they are in charge of domestic, emotional and social issues (Jiménez, 2009; Overbeke et al., 2013). Successors females are invisible successors, or successor by default (Eddleston \& Sabil, 2019; Lapeira \& Kundu, 2020). They are considered during periods of crisis (for example, in economic or health problems, or because of rejection of the brother), or when the owner has no other option to keep the business in the family (Dumas, 1989; Barbot, Bayad, Bourguiba \& Schmitt, 2005; Constantinidis \& Santin, 2008). According to Daspit (2016), the need for two-way communication is especially important for potential female successors who, at a young age, may benefit from generalized exchange relationships with others when the exchanges serve to minimize cultural or tradition-based opposition to their ascendancy (Fahed-Sreih \& Djoundourian, 2006; Vera \& Dean, 2005). Children, however, are not always interested in taking over the family firm (Stavrou, 1999). It is essential to generate commitment and responsibility, to give continuity to a common project (De la Garza, Medina, Cheín, Jiménez, Ayup, Díaz, 2011) and also suggested that they be allowed to select their level of involvement without parental pressure (Birley 2002).

To become a candidate for succession, the daughters are conditioned to have a record of accomplishment of professional experience outside the family business (Cadieux, Lorrain $\&$ Hugron, 2002). In this context, an important factor is the age, given that a position of res- 
ponsibility is offered up to an age between 40 and 50 years old. In addition, women is often invisible to clients, suppliers and a variety of other business partners who may disparage their contributions (Jiménez, 2009; Cesaroni, 2014).

The literature about female succession is scarce (Daspit, Holt, Chrisman \& Long, 2016; Campopiano, De Massis, Rinaldi \& Sciasciae, 2017; Overbeke, Bilimoria \& Perelli, 2013), and additionally, it can be considerable influenced for the cultural context (Welsh, Kaciak, Trimi \& Mainardes, 2017), or the kind of paternalism of the incumbent. For example, Sánchez-Famoso, Maseda and Erezuma (2017) emphasize the pertinence of the benevolent and moral styles in the succession of women.

Humphreys (2013) finds as a central issue, the transfer of leadership to the woman. In which the successor-title relationship with respect to the latter's necessary tutoring over the former, emphasizing the motivation of the former, and its emotional competence being a key quality. For its part, Overbeke et al. (2013) also believe that parental support and leadership mentoring facilitate the succession of daughters. Some relevant drivers are early socialization of daughters in the family business, better communication and quality of relationship father and daughters (Smythe \& Sardeshmukh, 2013). For Haberman and Danes (2007), father-daughter succession experience feelings of inclusion, resulting fewer conflicts and higher levels of shared meaning, collaborations and integration. Similarity, a benevolent paternalistic style of a male predecessor may increase the possibility of successful succession for a daughter (Cicellin, Mussolino \& Viganò, 2015).

Research about family business succession run by women show a lack of planning (see the qualitative study of Cadieux, Lorrain \& Hugron, 2002) (Martínez, Hernádez \& de la Poza, 2007). In accordance whit Hisrich and Fulop (1997), women are twice as likely as men to consider their daughters to take control of the business. So being women at the head of the family business has a positive impact on the next generations of women. Allen \& Langowitz (2003) found that women who own family businesses are 1.7 times more productive that those managed by men and are six times more likely to have a woman as a CEO. Nevertheless, daughters who succeeded their mother experienced succession difficulties in being compared to their mother's managerial style (Vera \& Dean, 2005). For a female CEO in is more difficult than a male CEO to choose a son/daughter-in-law as successor when he/she is not competent: when a daughter -in-law becomes successor, it is usually because she has outstanding skill (Kaslow, 1998). For Cesaroni et al., (2018) results show women founders, owners, and leaders of the family business, they never lost their role as emotional leader and these behaviors have proven to be very beneficial for the succession process and business survival.

Current studies are focusing significantly only on the demand of successor daughters, explaining how successor daughters have faced gender barriers (Glover 2014, Songini \& Gnan, 2009). But, they only examine the experiences of daughters who have gained positions of 
authority in the family business (Hytti, Heinonen \& Ljunggren, 2016; Hernández \& Gonzales, 2020). The absent consideration of factors influencing women succession, including the experiences of daughters who have not attempted succession, leads to the fact that literature has not fully explained the shortage of successor daughters. How it is this phenomenon or the general role and function of daughters of family businesses can be improved? (Overbeke et al., 2013).

The aim of this research is to identify different factors influencing the decision that successor will be a woman. To do so, we propose the next hypothesis:

$\mathrm{H}_{1}$ : Family and organizational characteristics have an impact on the successor gender in family firms.

\section{Methodology}

The present study is descriptive, exploratory, and causal, realized through a cross-sectional analysis with a sample of 652 family business. We consider a company as a family business when the same or related families own more than $50 \%$ of property, and at least one member of these is a member of the top management team. We can observe in the table 1 the distribution of the sample was used. This is a stratified sample considering four Mexican states, Puebla, Tamaulipas, Tlaxcala, and Quintana Roo. In each one of the strata, the selection was done across a random process. We collected this sample from the 2016 Directorio Estadístico Nacional de Unidades Económicas (DENUE) of the Instituto Nacional de Estadística y Geografía (INEGI) in Mexico.

Table 1

Family businesses sample by State and economic sector

\begin{tabular}{ccccccc}
\hline State & Commerce & Construction & Manufacturing & Services & Others & Total \\
\hline Puebla & 92 & 19 & 33 & 119 & 4 & 267 \\
Tamaulipas & 109 & 7 & 9 & 119 & 2 & 246 \\
Quintana Roo & 15 & 5 & 2 & 59 & 1 & 82 \\
Tlaxcala & 22 & 1 & 13 & 20 & 1 & 57 \\
\hline Total & 238 & 32 & 57 & 317 & 8 & 652 \\
\hline
\end{tabular}

Source: own elaboration.

The survey was conducted during August-October 2016, applying a questionnaire through the online software Qualtrics ${ }^{\circledR}$, complemented with phone calls. The data collected, for this study's purpose, included data about succession, ownership, strategic management practices, and governance bodies. As indicators of succession process, we collected information 
about gender that they would prefer when replacing a managerial position, gender of CEO, percentage of ownership held by women and men, generation, equality of wage, if the firm have or not a succession process.

Due to the characteristics of the variables and by the nature of the dependent variable (dichotomous), we use a logit model. Authors, such as Novales (1993), establish that this type of model is used when estimating the probability that an individual chooses the option Yi $=1$, using the logistic distribution function. In addition, Gujarati (2004) argues that logit modeling is one of the methods used to develop probability models with a binary response variable. We did not use the Ordinary Least Squares method (OLS) because it supposes a linear distribution of the explanatory variables. The logit model assumes a logistic distribution, so we applied the maximum likelihood estimation (MLE) as the estimation through this method provides consistent, efficient and asymptotically normal estimators of $\beta$ coefficients (Verbeek, 2008). Therefore, the logit model for the regression analysis is as follows:

(1) Logit $[\mathrm{P}($ successwom $=1)]$

$$
\begin{aligned}
& =\beta+\beta_{1} \text { genCEO }+\beta_{2} \text { womanown }+\beta_{3} \text { menown }+\beta_{4} \text { firstgen }+\beta_{5} \text { secondgen } \\
& +\beta_{6} \text { thirdgen }+\beta_{7} \text { equalwage }+\beta_{8} \text { sucessproc }+\beta_{9} \text { age }+\beta_{10} \text { size }+\beta_{11} \text { sector }+\varepsilon
\end{aligned}
$$

Where:

Dependent variable

- successwom: preference for a woman as successor (yes $=1$, no $=0$ )

Independents variables

- genCEO: CEO gender $($ woman $=1$, men $=0)$

- womanown: percentage of woman's property $(\%)$

- menown: percentage of men's property (\%)

- firstgen: first generation family firm

- secondgen: second generation family firm

- thirdgen: third generation family firm

- equalwage: existence of equal wages between men and women (yes $=1$, no $=0$ )

- successproc: existence of succession process $(\mathrm{yes}=1$, no $=0$ )

Control variables

We also incorporated three control variables in this research model.

- age: age in years since foundation (number).

- size: firm size (natural logarithm of number of employees).

- sector : industrial sector ( $1=$ construction, $2=$ manufacturing, $3=$ commerce, or $4=$ services $)$.

We present the descriptive statistics of the variables in table 2: 
Table 2

Descriptive Statistic

\begin{tabular}{lccccc}
\hline Variable & Obs & Mean & Std. Dev. & Min & Max \\
\hline successwom & 652 & 0.266871 & 0.442664 & 0 & 1 \\
genCEO & 652 & 0.332822 & 0.471585 & 0 & 1 \\
womanown & 652 & 0.446942 & 0.136537 & 0.1 & 0.75 \\
menown & 652 & 0.544955 & 0.193943 & 0.1 & 0.98 \\
fistgen & 652 & 0.687117 & 0.464023 & 0 & 1 \\
secondgen & 652 & 0.254601 & 0.435971 & 0 & 1 \\
thirdgen & 652 & 0.047546 & 0.212967 & 0 & 1 \\
equalwage & 652 & 0.509203 & 0.500299 & 0 & 1 \\
sucessproc & 652 & 0.185583 & 0.389068 & 0 & 1 \\
size & 652 & 34.41258 & 197.8261 & 5 & 4500 \\
age & 652 & 17.12883 & 15.20415 & 5 & 97 \\
commerce & 652 & 0.377301 & 0.485083 & 0 & 1 \\
services & 652 & 0.486196 & 0.500193 & 0 & 1 \\
manufacturing & 652 & 0.088957 & 0.2849 & 0 & 1 \\
construction & 652 & 0.047546 & 0.212967 & 0 & 1 \\
\hline
\end{tabular}

Source: own elaboration.

As we can see in table 2 , on average only $26 \%$ of the family businesses analyzed consider a woman for the succession process. The majority of the CEOs in the business analyzed are men, the percentage of men ownership is greater than women on average. Most of the business analyzed are first generation, which shows the problems that the family businesses in Mexico. The average age of family businesses is 17 and the average number of employees is 34. It's important to note that on average only $18 \%$ of business have defined a succession process. Finally, dominant sector are services and commerce.

\section{Results}

We run the logit regression model to analyze the effect of variables related to the succession process and their impact on the decision that successor will be a woman. Table 3 show the results of the regression. 
Table 3

Regression Analysis of Succession Woman Process

\begin{tabular}{lcccccc}
\hline successwom & Coef. & Std. Err. & $\mathrm{z}$ & $\mathrm{P}>\mathrm{z}$ & \multicolumn{2}{c}{ [95\% Conf. Interval] } \\
\hline genCEO & 0.936255 & 0.208706 & 4.49 & 0 & 0.527199 & 1.34531 \\
womanown & 0.188299 & 0.082464 & 2.28 & 0.022 & 0.026673 & 0.349925 \\
menown & -0.08112 & 0.068333 & -1.19 & 0.235 & -0.21505 & 0.05281 \\
fistgen & 0.325143 & 0.227225 & 1.43 & 0.152 & -0.12021 & 0.770495 \\
secondgen & 0.479275 & 0.57544 & 1.7 & 0.089 & -0.14857 & 2.107116 \\
thirdgen & 0.530341 & 0.580976 & 2.29 & 0.022 & 0.19165 & 2.469033 \\
equalwage & -0.12054 & 0.195119 & -0.62 & 0.537 & -0.50296 & 0.26189 \\
sucessproc & 0.276089 & 0.249918 & 1.1 & 0.269 & -0.21374 & 0.765919 \\
age & -0.03957 & 0.118293 & -0.33 & 0.738 & -0.27142 & 0.19228 \\
Size (Log) & -0.19947 & 0.08861 & -2.25 & 0.024 & -0.37314 & -0.02579 \\
commerce & 1.418279 & 0.581326 & 2.27 & 0.023 & 0.1789 & 2.457658 \\
services & 0.970725 & 0.575523 & 1.69 & 0.092 & -0.15728 & 2.098729 \\
manufacturing & 0.877086 & 0.652551 & 1.34 & 0.179 & -0.40189 & 2.156063 \\
construction & -1.31828 & 0.581326 & -2.27 & 0.023 & -2.45766 & -0.1789 \\
cons & -0.90489 & 0.444366 & -2.04 & 0.042 & -1.77583 & -0.03395 \\
\hline
\end{tabular}

Source: own elaboration.

As we can see in table 3, the variables that are significant and influence the choice of a woman as a successor are the gender of the current CEO (in this case it is a dummy that takes the value of 1 if the general direction is currently in hands of a woman and zero otherwise), therefore, if the managerial position are in woman hands, has a positive effect on the choice of female successor. The female ownership variable is also significant; therefore, greater men ownership has a negative impact on the woman successor election.

For the family generation variable, the results shows that in family business of first generation it does not seem feasible to choose a woman as successor, however, from the second generation the variable is significant, then second generations family business are more likelihood to considered incorporate a woman in the succession process, but in spite of being significant, this significance is very low, on the contrary, from third generation family business, the probability that women are chosen in the process of succession is much greater (the variable highly significant). Finally, the control variables such size, has a negative impact in the decision about select a woman in the succession process, then in larger business' lower probability to choose a woman as successor. For sectors, the results show that commerce and 
services are significant and positive, while construction it's significant but negative, then, in construction sector, women are not considered in the succession process. Regarding manufacturing sector, it was not significant.

\section{Conclusions}

Family businesses in Mexico are the main driver of the economy and, therefore, represent most economic units, due to their high contribution to gross domestic product (GDP) and employment. About these characteristics, there is a growing interest by academics in research about women in this type of business and in work related to the succession process. This process is a critical moment for the survival of the business that affects the stability of family ties; being, at the same time, a key challenge for the competitiveness of the family businesses (Hernández \& Gonzales, 2020; Lapeira \& Kundu, 2020).

In practice, this work highlights the main factors to facilitate participation of women like successors in family businesses. The main results show that the variables that are significant and influence the choice of a woman as a successor are the gender of the current CEO, therefore, if the managerial position are in woman hands, has a positive effect on the choice of female successor (Welsh et al., 2018). The female ownership variable is also significant; therefore, greater men ownership has a negative impact on the woman successor election. Also, most business are in the first and second generation, however, in the third generation there is a greater likelihood that women will be considered for the succession process, which could mean greater experience of the business in the generational transition and adequate planning in the succession process. Additionally, in smaller business' higher likelihood to choose a woman as successor. For sectors, the results show that the business dedicated to commerce and services are those that have a greater likelihood of choosing a woman as successor.

Regarding the limitations of research, it's necessary to emphasize that the study geographically refers to four states of Mexico. In addition, the study was carried out mostly with private micro, small and medium business, so the extension of the study to large and public business will help us understand the whole population of Mexican family businesses.

Future research like deepen explanation about factors of women's selection in third generation, identification of women succession profile and process for succession in this case is also interesting. In women successor, to recognize her motivations, the sense of obligation and responsibility of their roles. This future research is very important, knowing that empirical studies in Mexican family businesses about this topic, are scarce. The incorporation of the cultural perspective seems valuable to be considered in future lines of research. It is important to extend the studies to other countries, including Latin American ones and to make comparisons. 


\section{A. Soto Maciel, et al. / Contaduría y Administración 66(3), 2021, 1-14 \\ http://dx.doi.org/10.22201/fca.24488410e.2021.2482}

Our results will also contribute to Mexican family businesses themselves, guiding them in adopting the best practices for succession process. Also, a better understanding of Mexican family businesses will also help regional universities to update their study programs and develop educational programs on topics related to women successor selection in family businesses.

\section{References}

Ahrens, J. P., Landmann, A., \& Woywode, M. (2015). Gender preferences in the CEO successions of family firms: Family characteristics and human capital of the successor. Journal of Family Business Strategy, 6(2), 86-103. http//dx.doi.org/10.1016/j.jfbs.2015.02.002

Agarwal, J. (2019). Women Entrepreneurship and Innovations: Evidence From India. The international Journal Research Publications RJSSM, 08, 10, February , 64-68.

Allen, I. E. \& Langowitz, N.S. (2003). Woman in family own business report. Babson College/MassMutual Financial Group. Disponible en https://www.uvm.edu/sites/default/files/2003Women-in-Family-Owned-Businesses. pdf

Barbot, M. C., Bayad, M., Bourguiba, M., \& Schmitt, C. (2005). Comparative entrepreneurship: the case of father-to daughter family business transmission in France and Tunisia. International Council for Small Business, Washington.

Barnes, L. B. (1988). Incongruent hierarchies: Daughters and younger sons as company CEOs. Family Business Review, 1(1), 9-21. http//dx.doi.org/10.1111/j.1741-6248.1988.00009.x

Barnes, L. B., \& Hershon, S. A. (1976). Transferring power in family business. Harvard Business Review, 54(4), 105-114. http//dx.doi.org/10.1111/j.1741-6248.1994.00377.x

Bayad, M., Barbot, M. C. (2002). Proposition d'un modèle de succession dans les PME familiars: Étude de cas exploratoire de la relacion père-fille, Gème Congrès International Francophone en Entrepreneuriat et PME.

Belausteguigoitia, I. (2017). Empresas familiares: dinámica, equilibrio y consolidación. Cuarta edición. McGraw-Hill/Interamericana Editores, S.A. de C.V. México.

Beltrán, L.L., Haro, J.F., Bernal, F.F. \& Trueba, O.A. (2019). Impacto del liderazgo de la mujer en la empresa familiar. Revista Educateconciencia (22)23, 25-39.

Bertrand, M., Johnson, S., Samphantharak, K. \& Schoar, A. (2008). Mixing family with business: A study of Thai business groups and the families behind them. Journal of Financial Economics, 88, 466-498. https://doi. org/10.3386/w13738

Birley, S. (2002). Attitudes of owner-managers' children towards family and business issues. Entrepreneurship Theory and Practice, 26, 5-20. https://doi.org/10.1177/104225870202600301

Bork, D. (1986). Family business, risky business. AMACOM, American Management Association.

Briozzo,A., Albanese, D. y Santolíquido, D. (2017). Gobierno corporativo, financiamiento y género: un estudio de las pymes emisoras de títulos en los mercados de valores argentinos. Revista Contaduría y Administración,6, 2.2. http://dx.doi.org/10.1016/j.cya.2017.01.005

Cabrera-Suárez, K. (2005). Leadership transfer and the successor's development in the family firm. The Leadership Quarterly, 16(1), 71-96. http//dx.doi.org/10.1016/j.leaqua.2004.09.010

Cadieux, L., Lorrain, J. \& Hugron, P. (2002). Succession in women-owned family businesses: A case study. Family Business Review, 15(1), 17-30. http//dx.doi.org/10.1111/j.1741-6248.2002.00017.x

Camarena, M., Saavedra, ML. \& Ducloux, D. (2016). Un estudio de las PYME lideradas por mujeres en Latinoamérica, Revista Universitaria Ruta, 18(1), 1-27. Disponible en https://revistas.userena.cl/index.php/ruta/ article/view/789 


\section{A. Soto Maciel, et al. / Contaduría y Administración 66(3), 2021, 1-14 \\ http://dx.doi.org/10.22201/fca.24488410e.2021.2482}

Campopiano, G., De Massis, A., Rinaldi, F. R., \& Sciascia, S. (2017). Women's involvement in family firms: Progress and challenges for future research. Journal of Family Business Strategy, 8(4), 200-212. http//dx.doi. org/10.1016/j.jfbs.2017.09.001

Carr, J.C. Chrisman, J.J. Chua, J.H. \& Steiner, L.P. (2016). Family Firm Challenges in Intergenerational -Wealth Transfer. Special issue of Entrepreneurship Theory and Practice on Theories of Family Enterprise, 1197-1208. http//dx.doi.org/10.1111/etap.12240

Cesaroni, F. M. (2014). Women and family business. When women are left only minor roles. The History of the Family Journal. 19(3), 358-379. http//dx.doi.org/10.1080/1081602x.2014.929019

Cesaroni, F. M., Garcés, A. E. \& Sentuti, A. (2018). The role of emotional leader in women-owned family businesses. In Gender Issues in Business and Economics, 131-145. Springer, Cham. https://doi.org/10.1007/9783-319-65193-4_10

Chrisman, J. J., Chua, J. H. \& Sharma, P. (2005). Trends and directions in the development of a strategic management theory of the family firm. Entrepreneurship Theory and Practice, 29(5), 555- 576. http//dx.doi.or$\mathrm{g} / 10.1111 / \mathrm{j} .1540-6520.2005 .00098 . \mathrm{x}$

Chrisman, J.J., Chua, J.H., Le Breton-Miller, I., Miller, D. \& Steier,L.P. (2018). Governance Mechanisms and Family Firms. Entrepreneurship Theory and Practice, 42(2), 171-186.https://doi.org/10.1177\%2F1042258717748650.

Cicellin, M., Mussolino, D., \& Viganò, R. (2015). Gender diversity and father-daughter relationships: Understanding the role of paternalistic leadership in family firm succession. International Journal of Business Governance and Ethics, 10(1), 97-118. http//dx.doi.org/10.1504/ijbge.2015.068693

Constantinidis, C. (2010). Enterprise familiale et genre. Les enjeux de la succession pour les filles. Revue Francaise de Gestion. (1), 143-159. http//dx.doi.org/10.3166/rfg.200.143-159

Constantinidis, C. \& Santin, S. (2008). La reprise d'entreprise familiale par les filles d'entrepreneur: une

lectura en termes de genre. Ponencia, L'internationalisation des PME et ses conséquences sur les stratégie entrepreneuriales.

Daspit, J. J., Holt, D. T., Chrisman, J. J. \& Long, R. G. (2016). Examining family firm succession from a social exchange perspective: A multiphase, multistakeholder review. Family Business Review, 29(1), 44-64. http// dx.doi.org/10.1177/0894486515599688

Davis, P. (1983). Realizing the potential to the family business, Organizational Dynamics, 12(1), 47-56. http// dx.doi.org/10.1016/0090-2616(83)90026-8

De la Garza, M. I., Medina, J. M., Cheín, N. F., Jiménez, K. P., Ayup, J., Díaz, J. G. (2011). Los valores familiares y la empresa familiar en el Nordeste de México. Cuadernos de Administración, 24(42), 315-333. https://doi. org/10.11144/Javeriana.cao24-42.vfef.

De Massis, A., Chua, J. \& Chrisman, J. (2008). Factors preventing intra-family succession. Family Business Review, 21, 183-199. http//dx.doi.org/10.1111/j.1741-6248.2008.00118.x

De Massis, A., Sieger,P., Chua, J.H., \& Silvio, S. (2016). Incumbents' Attitude Toward Intrafamily Succession: An Investigation of Its Antecedents. Family Business Review, 29(3). 278-300. https://doi. org/10.1177/0894486516656276

Donnelley, R. (1988). The family business. Family Business Review, 1(4), 427-445. http//dx.doi.org/10.1111/ j.1741-6248.1988.00427.x

Dumas, C. (1989). Preparing the new CEO: Managing the father-daughter succession process in family business. Family Business Review, 2(1). 31-46. http//dx.doi.org/10.1111/j.1741-6248.1990.00169.x

Dumas, C. (1992). Integrating the daughter into family business management. Entrepreneurship Theory and Practice, 16(4), 41-56. http//dx.doi.org/10.1177/104225879201600403

Dumas, C. (1998). Women's pathways to participation and leadership in the family-owned firm. Family Business Review, 11(3), 219-228. http//dx.doi.org/10.1111/j.1741-6248.1998.00219.x

Dumas, C., Dupuis, J. P., Richer, F. \& St-Cyr, L. (1995). Factors that influence the next generation's decision to take-over the family farm. Family Business Review, 8(2), 99-120. http//dx.doi.org/10.1111/j.17416248.1995.00099.x 


\section{A. Soto Maciel, et al. / Contaduría y Administración 66(3), 2021, 1-14 \\ http://dx.doi.org/10.22201/fca.24488410e.2021.2482}

Eddleston, K.A. and Sabil, G. (2019), Women in Family Firms: Unsung Heroes of Business-owning Families, en: Crittenden, V.L. (Ed.) Go-to-Market Strategies for Women Entrepreneurs, Emerald Publishing Limited, pp. 185-194. https://doi.org/10.1108/978-1-78973-289.

Fahed-Sreih, J. \& Djoundourian, S. (2006). Determinants of longevity and success in Lebanese family business: an exploratory study. Family Business Review, 19, 225-234. https://doi.org/10.1111/j.1741-6248.2006.00071.x

Ferrón, J. M., Simón, J. C., Durán, J. \& San Martín, J. M. (2016). La sucesión e institucionalización de la empresa familiar en México. México: Editorial IMEF.

Gallo, M.A. \& Sveen, J. (1991). Internationalizing the family business, facilitating and restraining factors. Family Business Review, 4(2), 181-190. http//dx.doi.org/10.1111/j.1741-6248.1991.00181.x

Gallo, M. A. (1995). La empresa familiar. Texto y casos. Barcelona: Editorial Praxis.

Gallo, M. (2008). Ideas básicas para dirigir la empresa familiar. Barañáin, Navarra: Ediciones Universidad de Navarra.

Gherardi, S., \& Perrotta, M. (2016). Daughters taking over the family business: Their justification work within a dual regime of engagement. International Journal of Gender and Entrepreneurship, 8(1), 28-47. http://dx.doi. org/10.1108/JJGE-11-2014-0044.

Glover, J. (2014). Gender, power and succession in family farm business. International Journal of Gender and Entrepreneurship, 6(3), 276-295. http//dx.doi.org/10.1108/ijge-01-2012-0006

Gujarati, D. N. (2004). Econometría. México: McGraw-Hill.

Haberman, H. \& Danes, S. M. (2007). Father-daughter and father-son family business management transfer comparison: Family FIRO model application. Family Business Review, 20(2), 136-194. http//dx.doi.org/10.1111/ j.1741-6248.2007.00088.x

Hernández, A.B. \& Gonzales, J.P. (2020). The influence of family businesses and women directors on innovation, Applied Economics, Taylor \& Francis Journals, vol. 52(1), 36-51, January. http//dx.doi.org/10.1080/000 36846.2019 .1638496

Hisrich, R. D., \& Fulop, G. (1997). Women entrepreneurs in family business: The Hungarian Case. Family Business Review, 10(3), 281-302. http//dx.doi.org/10.1111/j.1741-6248.1997.00281.x

Humphreys, M. (2013) Daughter succession: a predominance of human issues, Journal of Family Business Management, 3(1), 24-44. http//dx.doi.org/10.1108/20436231311326472

Hytti, U., Heinonen, J. \& Ljunggren, E. (2016). Navigating the family business: a gendered analysis of identity construction of daughters. International Small Business Journal, 35(6), 665-686. http//dx.doi. org/10.1177/0266242616675924

Instituto Nacional de Estadística y Geografía (INEGI), (2015). Censos económicos 2014. Resultados definitivos consultado el 30 de agosto de 2016 en http://www.inegi.org.mx/est/contenidos/Proyectos/ce/ce2014/doc/presentacion/pprd_ce2014.pdf

Jiménez, R. M. (2009). Research on women in family firms. Family Business Review, 22(1), 53-64. http//dx.doi. org/10.1177/0894486508328813

Kammerlander, N. (2016). I want this firm to be in good hands: Emotional pricing of resigning entrepreneurs. International Small Business Journal, 34, 189-214. https://doi.org/10.1177/0266242614541287

Kaslow, F. W. (1998). Handling transitions from mother to son in the family business: The knotty isssues. Family Business Review, 11(3), 229-238. http//dx.doi.org/10.1111/j.1741-6248.1998.00229.x

Keating, N. C. \& Little, H. M. (1997). Choosing the successor in New Zealand family farms. Family Business Review, 10(2), 157-171. http//dx.doi.org/10.1111/j.1741-6248.1997.00157.x

Lapeira, L. \& Kundi, S. (2020). Daughters in the Spotlight: A Study on Becoming Legitimate Members of the Family Business, Academy of Management Global Proceedings Vol. Mexico, No. 2020.

Le Breton-Miller, I., Miller, D. \& Steier, L. P. (2004). Toward an integrative model of effective FOB succession. Entrepreneurship Theory and Practice, 28(4), 305-328. http//dx.doi.org/10.1111/j.1540-6520.2004.00047.x

Luan, Ch., Chen, Y., Huang, H. \& Wang, K. (2016). CEO succession decision in family businesses. A corporate governance perspective. Asia Pacific Management Review, XXX 1-7. http// dx.doi.org/10.1016/j. apmrv.2017.03.003 


\section{A. Soto Maciel, et al. / Contaduría y Administración 66(3), 2021, 1-14 \\ http://dx.doi.org/10.22201/fca.24488410e.2021.2482}

Martínez, R., Hernández, M. J., \& de la Poza, J. (2007). Trayectoria profesional de las hijas en la empresa familiar: de la infancia a la sucesión. En J. C. Ayala (Coord.), Conocimiento, innovación y emprendedores: camino al futuro. Logroño: Servicio de Publicaciones de la Universidad de la Rioja. España.

Moreno, J., Lafuente, E. \& Vaillant, Y. (2018). Gender diversity in the board, women's leadership and business performance. Gender in Management: An International Journal, 33(2), 104-122, https://doi.org/10.1108/GM05-2017-0058

Novales, A. (1993). Econometría. Madrid: McGraw-Hill.

Overbeke, K. K., Bilimoria, D. \& Perelli, S. (2013). The Dearth of daughter Successors in family businesses: Gendered norms, blindness to possibility, and invisibility, Journal of Family Business Strategy, 4(3), $201-212$. http//dx.doi.org/10.1016/j.jfbs.2013.07.002

Richards, M., Kammerlander, N. \& Zellweger, T. (2019). Listening to the heart or the head? Exploring the "willingness versus ability" succession dilemma. Family Business Review, 32(4), 330-353. https://doi. org/10.1177/08944865

Rosenblatt, P., De Mik, L., Anderson, R. \& Johnson, P. (1985). The family in business. San Francisco: Jossey-Bass.

Sánchez-Famoso, V., Maseda, A., \& Erezuma, I. (2017). Sucesión en la Empresa Familiar: Paternalismo y Género. Revista Espacios, 38(11).

Sharma, P., Chrisman, J., Pablo, A. \& Chua, J. (2001). Determinants of initial satisfaction with the succession process in family firms: a conceptual model. Entrepreneurship Theory and Practice. 25(3), 17-36. http//dx.doi. org/10.1177/104225870102500302

Schröder, E., Schmitt, E., \& Arnaud, N. (2011). Career choice intentions of adolescents with a family business background. Family Business Review, 24(4), 305-321. http// dx.doi.org/10.1177/0894486511416977.

Smythe, J., Sardeshmukh, S. R. (2013). Fathers and daughters in family business. Small Enterprise Research, 20(2), 98-109. http//dx.doi.org/10.5172/ser.2013.20.2.98

Songini, L. \& Gnan, L. (2009). Women, glass ceiling, and professionalization in family SMEs: A missed link. Journal of Enterprising Culture, 17(4), 497-525. http//dx.doi.org/10.1142/s0218495809000461

Soto, A., Garza, M. I., Esparza, J. L. \& San Martín, J. M. (2015). The influence of family relationships in the succession. A factorial analysis of Mexican enterprises. Journal of Family Business Management, 5(2), $238-256$. https://doi.org/10.1108/jfbm-11-2014-0036

Stavrou, E. (1999). Succession in family businesses: Exploring the effects of demographic factors on offspring intentions to join and take over the business. Journal of Small Business Management, 37(3), 43. http//dx.doi. org/10.4337/9781782547549.00017

Stern, M. H. (1986). Inside the family-held business. New York: Harcourt Brace Jovanovich.

Vera C. F. \& Dean M. A., (2005). An examination of the challenges daughters face in family business succession. Family Business Review, 18(4), 321-345. http//dx.doi.org/10.1111/j.1741-6248.2005.00051.x

Verbeek, M. (2008). A guide to modern econometrics. England: John Wiley \& Sons.

Welsh, D. H., Kaciak, E., Trimi, S. \& Mainardes, E. W. (2018). Women entrepreneurs and family firm heterogeneity: evidence from an emerging economy. Group Decision and Negotiation, 27(3), 445-465. https://doi. org/10.1007/s10726-017-9544-8 